\title{
KSZTAŁTOWANIE SIE WSPÓŁCZYNNIKA EFEKTYWNOŚCI POMPY CIEPLA PRZY WSPÓŁPRACY Z AKUMULATORAMI CIEPŁA O RÓŻNEJ POJEMNOŚCI
}

\begin{abstract}
W prezentowanej pracy przedstawiono wyniki analizy procesu ogrzewania budynku przy współpracy pompy ciepła z wodnymi akumulatorami ciepła izolowanymi termicznie od otoczenia, które stanowiły dolne źródła ciepła dla pompy. Rozważono kilka wodnych akumulatorów ciepła. W pierwszym etapie rozważań akumulatory w kształcie sześcianu różniły się objętością wody (pojemnością cieplną) i współczynnikami przenikania ciepła przez ich ściany, ale każdy z nich zapewniał ilość ciepła potrzebną do ogrzania budynku. Natomiast w następnej części, rozważono wodne akumulatory ciepła o takim samym współczynniku przenikania ciepła przez ściany, ale różniące się pojemnością cieplną.

Akumulator przejmował ciepło od absorberów słonecznych i gromadził to ciepło w okresie letnim. Przeprowadzona analiza wykazała, że w przypadku akumulatorów o dużej pojemności budynek może być ogrzewany w ciągu całego sezonu grzewczego bez udziału pompy ciepła, jedynie przy wykorzystaniu pompy obiegowej transportującej ciepło z akumulatora do ogrzewanego obiektu. Natomiast w przypadku akumulatorów o mniejszej pojemności jedynie w części sezonu grzewczego budynek może być ogrzewany w oparciu o wymianę ciepła pomiędzy akumulatorem a ogrzewanym budynkiem bez udziału pompy ciepła. W dalszej części sezonu grzewczego, gdy temperatura wody w akumulatorze obniży się, do ogrzewania włączona zostanie pompa ciepła dla której ten akumulator wodny byłby dolnym źródłem ciepła. Pozwoliłoby to osiągnąć bardzo wysoką średnioroczną wartość współczynnika wydajności pomp ciepła (COP).
\end{abstract}

Słowa kluczowe: kolektory słoneczne, akumulator ciepła, pompa ciepła.

\section{Wprowadzenie}

Temperatura dolnego źródła ciepła jest podstawowym czynnikiem decydującym o wartości współczynnika wydajności pompy ciepła. Ogólnie przebieg zmian temperatury dolnego źródła może być różny w zależności od rodzaju

\footnotetext{
${ }^{1}$ Autor do korespondencji: dr K. Stanisz, PWSZ im S. Pigonia w Krośnie, katsta1304@interia.pl

${ }^{2}$ Prof. dr hab. inż. S. Gumuła, AGH w Krakowie, kmiue@imir.agh.edu.pl
} 
dolnego źródła ciepła i pory roku, przy czym znaczne zmiany temperatury mogą występować w bardzo krótkich odstępach czasu. W instalacjach posiadających pompy ciepła, dolnym źródłem jest zazwyczaj powietrze, grunt, woda gruntowa, ścieki komunalne, czy też duże, otwarte zbiorniki wodne. Część tych źródeł wykazuje złą koherentność z zapotrzebowaniem na ciepło, gdyż podczas największego zapotrzebowania na ciepło ich moc cieplna jest często najniższa.

Do magazynowania ciepła w celach grzewczych wykorzystuje się złoża kamienne, grunt a także materiały zmieniające fazę skupienia tj. np. hydraty lub parafiny. Jednak w zakresie niskich temperatur do akumulowania ciepła najbardziej nadaje się woda, która posiada prawie dwukrotnie większe ciepło właściwe niż inne czynniki dotychczas stosowane do tego celu. Dodatkowymi korzyściami pochodzącymi z jej wykorzystania jest niska jej cena, dostępność i nietoksyczność. Wadą wody jest natomiast ograniczenie temperatury akumulacji, która musi być niższa od temperatury wrzenia.

W prezentowanej pracy przedstawiono wyniki analizy parametrów współpracy pompy ciepła $\mathrm{z}$ wodnym akumulatorem ciepła izolowanym termicznie od otoczenia, który stanowił dolne źródło ciepła dla pompy ciepła. Rozważono kilka wariantów wodnych akumulatorów ciepła o takim samym współczynniku przenikania ciepła, ale różniących się objętością.

\section{Zapotrzebowanie budynku na ciepło dla celów grzewczych}

Obiektem ogrzewanym, dla którego przeprowadzono obliczenia, był budynek mieszkalny o powierzchni $110 \mathrm{~m}^{2}$ i zapotrzebowaniu na ciepło użytkowe $40 \mathrm{kWh} / \mathrm{m}^{2} /$ rok. Sezonowe zapotrzebowanie na ciepło wynosi wówczas $4400 \mathrm{kWh} /$ rok. Założono, że budynek będzie ogrzewany ciepłem zakumulowanym $\mathrm{w}$ wodnym akumulatorze ciepła, pozyskiwanym $\mathrm{z}$ energii promieniowania słońca za pomocą kolektorów słonecznych. Czas trwania sezonu grzewczego przyjęto 202 dni [1].

\section{Określenie pojemności akumulatora ciepła}

W pracy przyjęto, że akumulatorem ciepła będzie zbiornik wodny, którego maksymalna temperatura wody przed rozpoczęciem sezonu grzewczego może osiągnąć $90^{\circ} \mathrm{C}$, a po sezonie grzewczym temperatura wody nie spadnie poniżej $5^{\circ} \mathrm{C}[2]$.

$\mathrm{Na}$ podstawie obliczonego zapotrzebowania na ciepło dla celów grzewczych $\left(\mathrm{q}_{\mathrm{bp}}\right)$, oraz ciepła traconego na przewodach i w akumulatorze $\left(\mathrm{q}_{\mathrm{str}}\right)$, określono parametry techniczne możliwych do zastosowania wodnych akumulatorów ciepła oraz możliwą do zgromadzenia w tych akumulatorach ilość ciepła $q_{a k}$.

$$
q_{s t r}+q_{b p}=q_{a k} \quad[k W h]
$$


Przyjęte do analizy dane techniczne tych akumulatorów zestawiono $\mathrm{w}$ tabeli 1 . W pierwszym etapie rozważań akumulatory $\mathrm{w}$ kształcie sześcianu różniły się objętością wody (pojemnością cieplną) i współczynnikami przenikania ciepła przez ich ściany, ale każdy z nich zapewniał ilość ciepła potrzebną do ogrzania budynku określoną w punkcie drugim.

Tabela 1. Parametry techniczne akumulatorów ciepła

Table 1. Specifications of heat accumulators

\begin{tabular}{|l|c|c|c|c|}
\hline Objętość wody w akumulatorze $\left[\boldsymbol{m}^{\mathbf{3}}\right]$ & $\mathbf{6 5}$ & $\mathbf{9 0}$ & $\mathbf{1 5 0}$ & $\mathbf{2 7 0}$ \\
\hline $\begin{array}{l}\text { Współczynnik przenikania ciepła U przez ściany } \\
\text { akumulatora }\left[\mathrm{W} /\left(m^{2} * \mathrm{~K}\right)\right]\end{array}$ & $\leq 0,05$ & $\leq 0,1$ & $\leq 0,2$ & $\leq 0,3$ \\
\hline Możliwe do zgromadzenia ciepło $\left(q_{a k}\right)[\mathrm{kWh}]$ & 6409 & 8874 & 14790 & 26620 \\
\hline Przybliżone straty ciepła $\left(\mathrm{q}_{\mathrm{str}}\right)[\mathrm{kWh}]$ & 1643 & 3851 & 10030 & 20930 \\
\hline
\end{tabular}

Ostatecznie dla rozważanego budynku wybrano wodne akumulatory ciepła o współczynniku przenikania ciepła przez ścianki akumulatora wynoszącym 0,1 $\mathrm{W} /\left(\mathrm{m}^{2} * \mathrm{~K}\right)$. Rozważono kilka takich akumulatorów ciepła w kształcie sześcianu różniących się objętością (tabela 2).

Straty ciepła do otoczenia zostały obliczone z wzoru (2).

$$
q_{s t r}=P_{c} \cdot U \cdot \Delta T \cdot t \quad[W h]
$$

gdzie: $P_{c^{-}}$całkowita powierzchnia akumulatora ciepła $\left[m^{2}\right]$,

U- współczynnik przenikania ciepła akumulatora [W/ $\left.\left(\mathrm{m}^{2} * \mathrm{~K}\right)\right]$,

$\Delta T$ - różnica temperatur pomiędzy dolnym źródłem ciepła a temperaturą, powietrza zewnętrznego [K],

$\mathrm{t}$ - czas trwania sezonu grzewczego [ $\mathrm{h}]$.

Tabela 2. Parametry techniczne akumulatorów ciepła

Table 2. Specifications of heat accumulators

\begin{tabular}{|l|c|c|c|c|}
\hline Objętość wody w akumulatorze $\left[\mathbf{~ m}^{\mathbf{3}}\right]$ & $\mathbf{9 0}$ & $\mathbf{1 2 0}$ & $\mathbf{1 6 0}$ & $\mathbf{2 0 0}$ \\
\hline $\begin{array}{l}\text { Współczynnik przenikania ciepła U przez } \\
\text { ściany akumulatora }\left[\mathrm{W} /\left(\mathrm{m}^{2} * \mathrm{~K}\right)\right]\end{array}$ & $\leq 0,1$ & $\leq 0,1$ & $\leq 0,1$ & $\leq 0,1$ \\
\hline Możliwe do zgromadzenia ciepło $[\mathrm{kWh}]$ & 8874 & 11832 & 15777 & 19720 \\
\hline Straty ciepła do otoczenia $[\mathrm{kWh}]$ & 3851 & 4790 & 5880 & 6980 \\
\hline
\end{tabular}

W celu policzenia $\Delta T$ - różnicy temperatur pomiędzy temperaturą dolnego źródła ciepła a temperaturą powietrza zewnętrznego - wykorzystano dane pomiarowe przebiegu temperatur zewnętrznych przedstawione w pracy [1]. Obliczenia zostały wykonane w programie Excel dla każdego dnia sezonu grzewczego. 


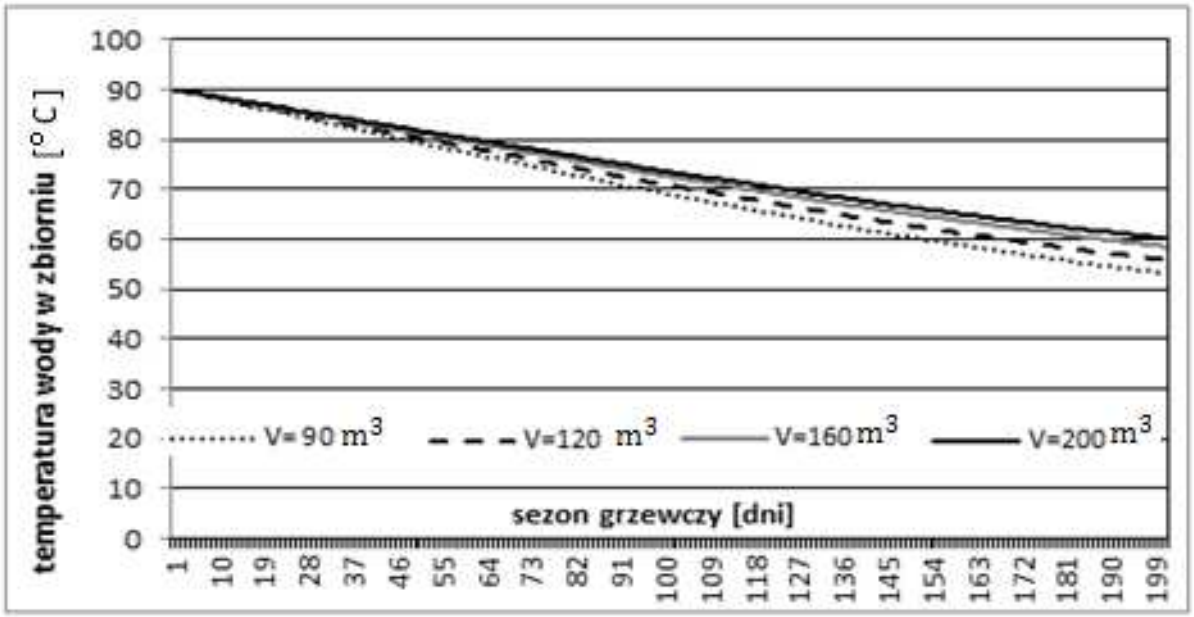

Rys. 1. Przebieg obniżania się temperatury wody w akumulatorze ciepła o współczynniku przenikania ciepła $\mathrm{U}=0,1 \mathrm{~W} /\left(m^{2} * \mathrm{~K}\right)$ ale o różnych pojemnościach w całym sezonie grzewczym na skutek strat ciepła do otoczenia

Fig.1. The distribution of water temperature decrease in a heat accumulator with a heat transfer coefficient $\mathrm{U}=0,1 \mathrm{~W} /\left(\mathrm{m}^{2} * \mathrm{~K}\right)$ but of different thermal capacities throughout the heating season due to heat losses to the environment

Następnie obliczono przebieg obniżania się temperatury wody w rozważanych akumulatorach ciepła (rys.1).

Temperatura wody w akumulatorze ciepła obniża się na skutek poboru ciepła do celów grzewczych oraz strat ciepła do otoczenia (tabela 3).

Tabela 3. Parametry techniczne akumulatorów ciepła

Table 3. Specifications of heat accumulators

\begin{tabular}{|l|c|r|r|r|}
\hline Objętość wody w akumulatorze $\left[\mathbf{~ m}^{3}\right]$ & $\mathbf{9 0}$ & $\mathbf{1 2 0}$ & $\mathbf{1 6 0}$ & \multicolumn{1}{|c|}{$\mathbf{2 0 0}$} \\
\hline $\begin{array}{l}\text { Współczynnik przenikania ciepła U przez } \\
\text { ściany akumulatora }\left[\mathrm{W} /\left(\mathrm{m}^{2} * \mathrm{~K}\right)\right]\end{array}$ & $\leq 0,1$ & $\leq 0,1$ & $\leq 0,1$ & $\leq 0,1$ \\
\hline Możliwe do zgromadzenia ciepło $[\mathrm{kWh}]$ & 8874 & 11832 & 15777 & 19720 \\
\hline $\begin{array}{l}\text { Przybliżone straty ciepła do otoczenia } \\
{[\mathrm{kWh}]}\end{array}$ & 2864 & 3860 & 5028 & 6137 \\
\hline Całe stracone i wykorzystane ciepło $[\mathrm{kWh}]$ & 7264 & 8260 & 9428 & 10537 \\
\hline
\end{tabular}

$\mathrm{Na}$ podstawie przebiegu bieżącego zapotrzebowania na ciepło ogrzewanego obiektu czyli przebiegu poboru ciepła z akumulatora oraz strat ciepła do otoczenia, określono przebieg obniżenia się temperatury $\mathrm{w}$ akumulatorach ciepła o różnych pojemnościach, ale o tym samym współczynniku przenikania ciepła (rysunek 2). 
Na zwrócenie uwagi zasługuje fakt, że straty ciepła do otoczenia są mniejsze w przypadku gdy ciepło odpływa $\mathrm{z}$ akumulatora równocześnie dla celów grzewczych i na skutek strat niż gdyby odpływało tylko na skutek strat. (tabela 4). Jest to spowodowane tym, że straty ciepła do otoczenia są związane z różnicą temperatur wody $\mathrm{w}$ akumulatorze a temperaturą otoczenia akumulatora $(\Delta \mathrm{T})$, i w przypadku gdy ciepło $\mathrm{z}$ akumulatora jest również pobierane do celów grzewczych, to ta różnica temperatur staje się coraz mniejsza.

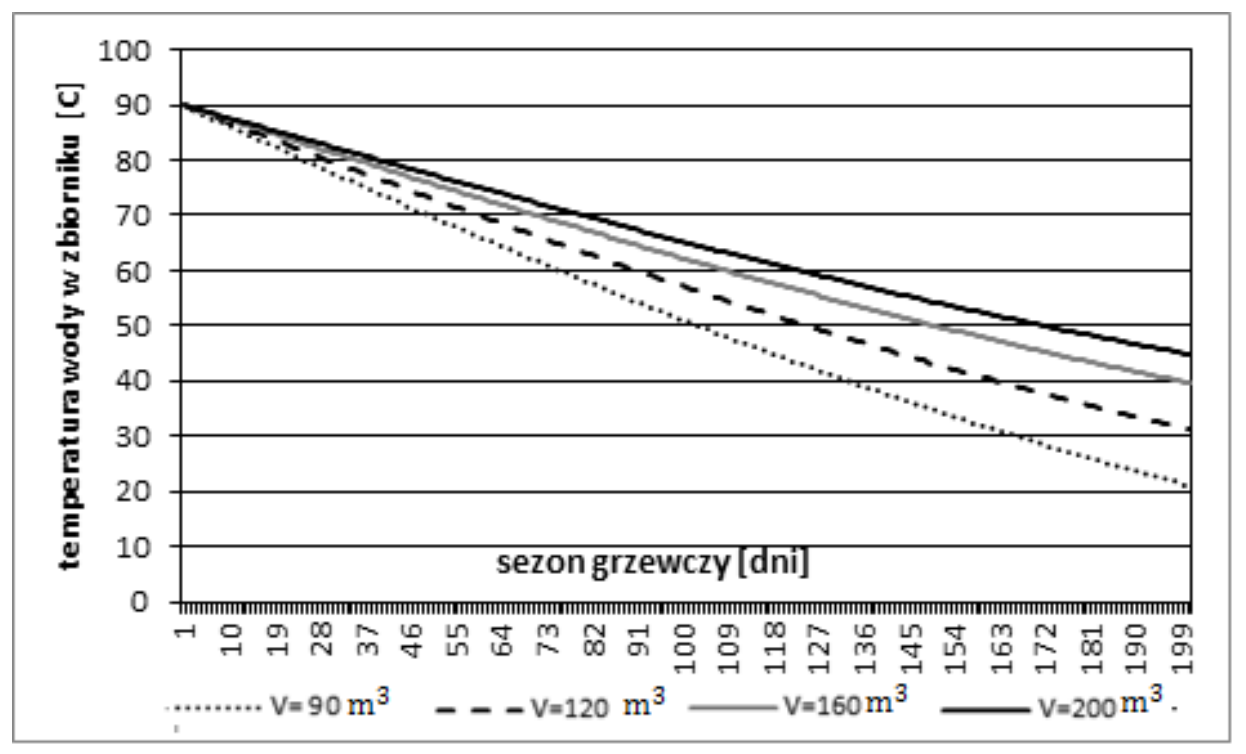

Rys.2. Przebieg procesu obniżania się temperatury w akumulatorach ciepła (dolnych źródłach ciepła pompy ciepła)

Fig.2. The process of lowering the temperature of the storage warm (lower heat source heat pumps)

Tabela 4. Porównanie strat ciepła w akumulatorach ciepła o różniej pojemności, w przypadku gdy ciepło jest pobierane dla celów grzewczych i nie jest pobierane dla celów grzewczych

Table 4. Comparison of the heat losses in the storage of differing thermal capacity, in two cases when used for heating purposes and when it is not used for heating purposes

\begin{tabular}{|l|c|c|c|c|}
\hline Objętość wody w akumulatorze $\left[\mathbf{~ m}^{\mathbf{3}}\right.$ ] & $\mathbf{9 0}$ & $\mathbf{1 2 0}$ & $\mathbf{1 6 0}$ & $\mathbf{2 0 0}$ \\
\hline $\begin{array}{l}\text { Przybliżone straty ciepła do otoczenia w } \\
\text { przypadku gdy ciepło nie jest pobierane do } \\
\text { celów grzewczych [ kWh ] }\end{array}$ & 3851 & 4790 & 5880 & 6980 \\
\hline $\begin{array}{l}\text { Przybliżone straty ciepła do otoczenia w } \\
\text { przypadku gdy ciepło jest również pobie- } \\
\text { rane do celów grzewczych } \\
\text { [kWh ] }\end{array}$ & 2864 & 3860 & 5028 & 6137 \\
\hline Różnica [kWh ] & 987 & 930 & 852 & 843 \\
\hline
\end{tabular}




\section{Sezonowe zmiany parametrów pracy układu ogrzewania bu- dynku}

Z rysunku 2 można wnioskować, że w przypadku akumulatorów o pojemności $160 \mathrm{~m}^{3}$ i $200 \mathrm{~m}^{3}$ - zgromadzona w akumulatorze ilość ciepła pozwala w całym sezonie grzewczym ogrzewać obiekt ciepłem zawartym w akumulatorze bez udziału pompy ciepła to znaczy w oparciu o wymianę ciepła wymuszoną jedynie pompą obiegową. Jedynie w przypadku akumulatorów ciepła o mniejszej pojemności, pompa ciepła będzie niezbędna i włączy się ona do pracy wówczas gdy temperatura wody w akumulatorze obniży się do takiej wartości, że nie da się ogrzewać obiektu jedynie na drodze wymiany ciepła pomiędzy akumulatorem ciepła a ogrzewanym obiektem. W tym momencie do procesu ogrzewania obiektu włączona zostaje pompa ciepła dla której akumulator będzie dolnym źródłem ciepła.

W oparciu o przebieg obniżania się temperatury w akumulatorze ciepła ze wzoru (3) określić można przebieg współczynnika wydajności pompy ciepła $\mathrm{CO} P_{c}$, definiowany w oparciu o obieg Carnota $[3,7]$.

$$
\mathrm{COP}_{c}=\frac{T_{g}}{T_{g}-T_{d}}
$$

gdzie: $T_{g}$ - temperatura górnego źródła ciepła,

$T_{d}$ - temperatura dolnego źródła ciepła.

Określony za pomocą wzoru (3) współczynnik efektywności pompy ciepła jest współczynnikiem maksymalnym, nie możliwym do osiągnięcia w obiektach rzeczywistych. Dla obiektów rzeczywistych relacja (3) obowiązuje ale wymaga pomnożenia przez współczynnik korygujący, który mieści się zazwyczaj w granicach od 0,55 do 0,65 . Obniżenie teoretycznej wartości współczynnika wydajności dla obiektów rzeczywistych wynika ze strat ciepła w przewodach łączących elementy pompy ciepła, straty przepływowe we wszystkich elementach pompy ciepła oraz straty energii w układzie napędowym. Do dalszej analizy przyjmiemy wartość współczynnika korygującego równą 0,55 .

Współczynnik ten jest tym wyższy, im mniejsza jest różnica temperatur pomiędzy temperaturą źródła dolnego a źródła górnego [3,7]. Dlatego najlepsze wskaźniki osiąga się wykorzystując pompy ciepła w układach grzewczych nisko temperaturowych, to znaczy takich, w których temperatura źródła górnego będzie możliwie jak najniższa, np. ogrzewanie podłogowe. W pracy została przyjęta temperatura górnego źródła ciepła wynosząca do $+40^{\circ} \mathrm{C}$. 


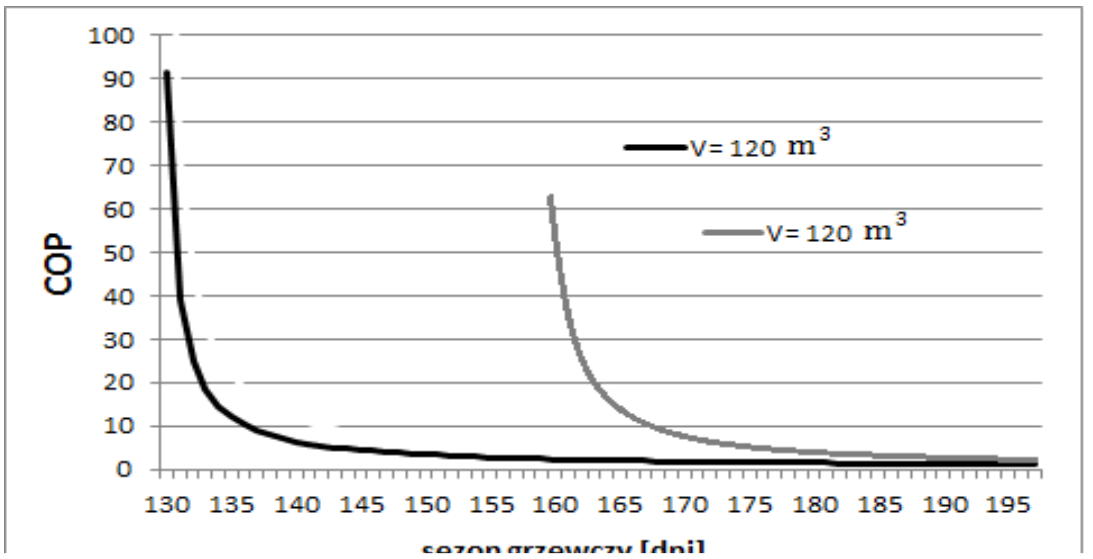

Rys.3. Przebieg współczynnika wydajności pompy ciepła (COP) w okresie ogrzewania obiektu $\mathrm{z}$ wykorzystaniem pompy ciepła przy różnych pojemnościach akumulatorów

Fig. 3. Changes of heat pump coefficient of performance (COP) during the heating of on object by a heat pump at different storage capacities

Przebieg wartości współczynnika COP dla całego okresu grzewczego z udziałem pompy ciepła pokazano na rysunku 3.

W przypadku akumulatora ciepła o pojemności $90 \mathrm{~m}^{3}$ pompa ciepła została włączona do pracy około 130 dnia sezonu grzewczego i średnia wartość współczynnika COP na przestrzeni całego roku wynosiła wówczas 8,8 . Natomiast $\mathrm{w}$ przypadku akumulatora ciepła o pojemności $120 \mathrm{~m}^{3}$ pompa ciepła została włączona do pracy około 160 dnia sezonu grzewczego i średnia wartość współczynnika COP wynosiła wówczas 5,5. Jest to bardzo wysoka wartość współczynnika COP.

\section{Oszacowanie potrzebnej powierzchni absorberów}

Znając możliwą ilość zgromadzonego ciepła w akumulatorze ciepła $\left(\mathrm{q}_{\mathrm{ak}}\right)$, sumaryczną wartość energii promieniowania słonecznego $\left(\mathrm{q}_{\mathrm{ps}}\right)$ [1], sprawność kolektorów $(\eta)$ (przyjęto, że dla kolektora płaskiego sprawność wynosi $50 \%$, natomiast dla kolektora próżniowego $70 \%$ [4,5]), ze wzoru 4 można określić wymaganą powierzchnię kolektorów słonecznych $\left(\mathrm{P}_{\mathrm{w}}\right)$ (tabela 5).

$$
P_{w} \cdot q_{p s} \cdot \eta=q_{a k} \quad[k W h]
$$

Wyznaczając całkowitą powierzchnię absorbera uwzględnić należy również straty ciepła $\mathrm{w}$ przewodach pomiędzy kolektorami a akumulatorem ciepła. Orientacyjnie na każde kolejne 10 metrów długości tych przewodów powierzchnię kolektorów zwiększa się o 8-10\% [6]. Istnieje jednak możliwość zastosowania znacznie lepszej izolacji cieplnej dla przewodów. 
Tabela 5. Zależność pomiędzy objętością akumulatorów ciepła a typem i ilością absorberów

Table 5. The relationship between the volume and the type of storage heat and aperture of area of solar absorbers

\begin{tabular}{|l|l|c|c|c|c|}
\hline \multicolumn{2}{|l|}{ Objętość wody w akumulatorze $\left[\mathbf{~ m}^{\mathbf{3}}\right]$} & $\mathbf{9 0}$ & $\mathbf{1 2 0}$ & $\mathbf{1 6 0}$ & $\mathbf{2 0 0}$ \\
\hline $\begin{array}{l}\text { Współczynnik przenikania ciepła U przez } \\
\text { ściany akumulatora }\left[\mathrm{W} / \mathrm{m}^{2} * \mathrm{~K}\right]\end{array}$ & $\leq 0,1$ & $\leq 0,1$ & $\leq 0,1$ & $\leq 0,1$ \\
\hline $\begin{array}{l}\text { Powierzchnia kolekto- } \\
\text { rów }\left[\mathrm{m}^{2}\right]-\mathrm{P}_{\mathrm{w}}\end{array}$ & płaski & 19 & 26 & 35 & 43 \\
\cline { 2 - 6 } & próżniowy & 14 & 19 & 26 & 32 \\
\hline
\end{tabular}

Zgromadzenie w akumulatorze wodnym tak dużej ilości ciepła w okresie letnim wymaga wprowadzenia do strumienia cieczy transportującej ciepło od kolektorów do akumulatora pompy obiegowej. Pompa będzie transportować ciepło w okresach gdy temperatura $w$ kolektorach będzie wyższa od temperatury w akumulatorze. Taki układ pozwoli maksymalnie wykorzystać moc promieniowania słońca do akumulacji ciepła w akumulatorze.

\section{Podsumowanie i wnioski}

Wykorzystanie do ogrzewania budynku pompy ciepła, współpracującej $\mathrm{z}$ izolowanym termicznie odpowiednio dobranym, wodnym akumulatorem ciepła pozwala zapewnić całkowitą ilość ciepła potrzebną do ogrzania budynku w całym sezonie grzewczym. Zaproponowany sposób ogrzewania budynku całkowicie eliminuje lokalny proces spalania w budynku i lokalną emisję produktów spalania. Nie eliminuje jednak spalania całkowicie, ponieważ energia elektryczna potrzebna do napędu sprężarki i pomp obiegowych jest wytwarzana w większości w elektrowniach zawodowych cieplnych. W elektrowniach zawodowych możliwości eliminowania ze spalin szkodliwych produktów spalania jest nieporównywalnie większa niż w kotłowniach indywidualnych. W kotłowniach indywidualnych praktycznie takich możliwości nie ma. Zatem zaproponowane rozwiązanie $\mathrm{z}$ punktu widzenia eksploatacji posiada znaczne walory ekologiczne- ograniczenie zużycia paliwa i korzystanie z energii elektrycznej produkowanej z troską o ekologię.

Przy zaproponowanym rozwiązaniu w przypadku większych akumulatorów obiekt może być ogrzewany poprzez wymianę ciepła pomiędzy ogrzewanym obiektem a akumulatorem ciepła bez udziału pompy ciepła. Zasilania energią elektryczną wymaga tylko pompa obiegowa transportująca ciepło $\mathrm{z}$ akumulatora do obiektu za pośrednictwem cieczy przepływającej przez wymienniki $\mathrm{w}$ akumulatorze i $\mathrm{w}$ budynku. Natomiast $\mathrm{w}$ przypadku mniejszych akumulatorów pompa ciepła będzie niezbędna w drugiej części sezonu grzewczego. Zaproponowane rozwiązanie pozwoliło osiągnąc bardzo wysoką wartość średnią współczynnika wydajności pompy ciepła. 


\title{
Literatura
}

[1] Gumuła S, Stanisz K.: Warianty rozwiazań technicznych zapotrzebowania na energię elektryczna budynku niezależnego energetycznie. Prace Naukowe Politechniki Warszawskiej, s. Konferencje, z. 26, Warszawa 2009.

[2] Kaiser H. Wykorzystanie energii stonecznej. Wydawnictwo AGH. Kraków 1995.

[3] Rubik Marian: Pompy ciepta. Poradnik. Ośrodek Informacji „Technika instalacyjna w budownictwie". Wyd. 3 rozsz. Warszawa 2006.

[4] Smolec W. Fototermiczna konwersja energii słonecznej. Wydawnictwo PWN, Warszawa 2000.

[5] Tytko R.: Odnawialne źródła energii. OWG Warszawa 2009.

a. Wesołowski M.: Vademecum dla przedsiębiorców. Cieczowe systemy słoneczne. (http://wmzdz.pl/fileadmin/user_upload/wmzdz/publikacje/01_Wyd_A_WEB.pdf).

[6] Zawadzki M.: Kolektory stoneczne, Pompy ciepła - Na Tak Wydawnictwo Zawadzki 2003.

\section{EVOLUTION OF THE COEFFICIENT OF PERFORMANCE OF THE HEAT PUMP IN CONJUNCTION WITH HEAT BATTERIES OF DIFFERENT CAPACITIES}

\begin{abstract}
S u m m a r y
The paper presents the results of the building heating process analysis, in cooperation of a heat pump with water thermally insulated from the environment heat accumulators, which were lower heat source for the pump. Several water heat accumulators were considered . In the first stage, the cube-shaped batteries differed in the volume of water (heat capacity) and the heat transfer coefficients of the wall, but each of them provided the quantity of heat needed to heat the building. However, in the next section, water heat accumulators of the same heat transfer coefficient of the wall were considered, but with a different heat capacity.

The battery took the heat from solar absorbers and collected it in the summer. The analysis showed that in the case of high-capacity batteries a building can be heated during the whole heating season without the heat pump, only by using the heat pump of the accumulator conveyor to the heated object. However, in the case of smaller capacity batteries with only part of the heating season, the building can be heated without the heat pump. In the remainder of the heating season, when the water temperature in the battery becomes low, the heat pump, for which the battery water would lower the heat source, will be activated. This would allow to achieve a very high average annual value of the heat pump performance coefficient (COP).
\end{abstract}

Keywords: solar panels, battery heat, heat pump.

Przestano do redakcji: 09.01.2015 r.

Przyjęto do druku: 22.06.2015 r.

DOI:10.7862/rb.2015.71 
